\title{
PROLOGUE
}

\author{
First Impressions
}

One day as Spain's colonies sat poised on the edge of their independence, the Indian woman María Magdalena decided to leave her home of many years and head for the city of Guayaquil with her young daughter, Ana Yagual. Together they departed from the coastal fishing village where they had lived in great hardship and began a sixty-mile journey up the River Guayas. ${ }^{1}$ They went partway on foot and partway by raft. Along both sides of the river, leafy plants touched the gray water. Wherever mangrove bushes grew, they were perfectly reflected in the calm of the río, making it almost impossible to tell where the water began and ended.

To avoid answering questions, many newcomers waited until after dark to approach the city. Perched on rafts and boats, they stared at the populous riverbank, for at night the town appeared almost magical. Two horizontal rows of lights glittered for half a mile, the bottom row cast by street lamps and the top by lights in the upper floors of the stately white houses lining the shore. Giant palm trees grew along the river's edge. Those who waited on the water could hear strains of music clearly. To the right, at the foot of green hills, people who lived on balsas or small boats had lit fires aboard their crafts, and the sound of their laughing and talking floated across the surface of the water. Canoes darted in and out expertly, as if the darkness were no obstacle. The sight even made an impression on wealthy and well-traveled foreigners standing on the decks of big ships. "It was 
late in the evening when we came to anchor off the city, and I never beheld a more brilliant view than the one before us." 2

But the lights shimmered almost too brightly. Another visitor later warned: "And when you finally reach the end of your voyage and stop before the vision of an enchanted city looking in from the outside, then if you want to keep your illusion unbroken and your poetic memories intact, you must not enter." ${ }^{3}$ Either María Magdalena had never been to this world before or she did know something of it yet felt prepared to negotiate its pitfalls. She chose to enter, heading up one of the estuaries toward the outskirts of town, where she would make her home, with Ana Yagual right behind her.

Only a few years later in the 1820 s, but thousands of miles to the north, another child entered another port. Frederick Bailey was about ten when his Talbot County master sent him to live in Baltimore. He could barely contain his excitement. "My cousin Tom had been there," he would later write, "... and when he came from Baltimore, he was always a sort of hero amongst us ... I could never tell him anything that struck me as beautiful or powerful, but that he had seen something in Baltimore far surpassing it." Now Frederick himself had been sent to live with one of his owner's urban relations, to work as an errand boy and domestic servant. ${ }^{4}$

The wide waters of the Chesapeake formed the main approach to town. From a ship or a boat the city's appearance could be breathtaking, and travelers remembered the sight. "Baltimore, with its white buildings rising to our view on the sides of the hills as we approached it, had a most exhilarating effect." ${ }^{5}$ But first contact with the actual wharves indicated to some that life in this city would hardly prove to be idyllic. The shallow waters were dumping grounds for refuse and, especially in summer, became "reservoirs of putrefaction." "We came along the wharf sides, under the red dingy-looking warehouses, between which the water ran in narrow dark-looking canals." 6

Frederick Bailey's boat docked at Smith's Wharf on a summer Sunday morning. Some of the passengers drove a large flock of sheep they had on board to a nearby slaughterhouse. The boy's initial enthusiasm waned quickly, as his early impressions of the city were not very favorable after all. For a while he wanted to leave, "with hard brick pavements under my feet, which almost raised blisters by their very heat, ... walled in on all sides by towering brick buildings; with troops of boys ready to pounce upon me at every street corner ... ; and with startling sounds reaching my ears from all directions." 7 Not long after, the child also came to 
understand the full meaning of the word "slave," increasing his sense of entrapment as he got to know the city better. Yet as the years passed, Frederick became convinced that city life was to be his salvation, his path out of slavery and then out of poverty.

As Frederick in Baltimore and Ana Yagual in Guayaquil grew and neared adulthood, they learned to negotiate the daily workings of their respective worlds and became familiar with the opportunities open and closed to them. They learned to what extent their optimism was misplaced and to what extent well founded. Then they made decisions and took action based upon their sense of themselves and their knowledge of the societies in which they lived. In the coming chapters I ask the reader to follow them through the streets of their cities and let the details of their lives illuminate both the potential and the constraints of the worlds they inhabited. 
THIS PAGE INTENTIONALLY LEFT BLANK 


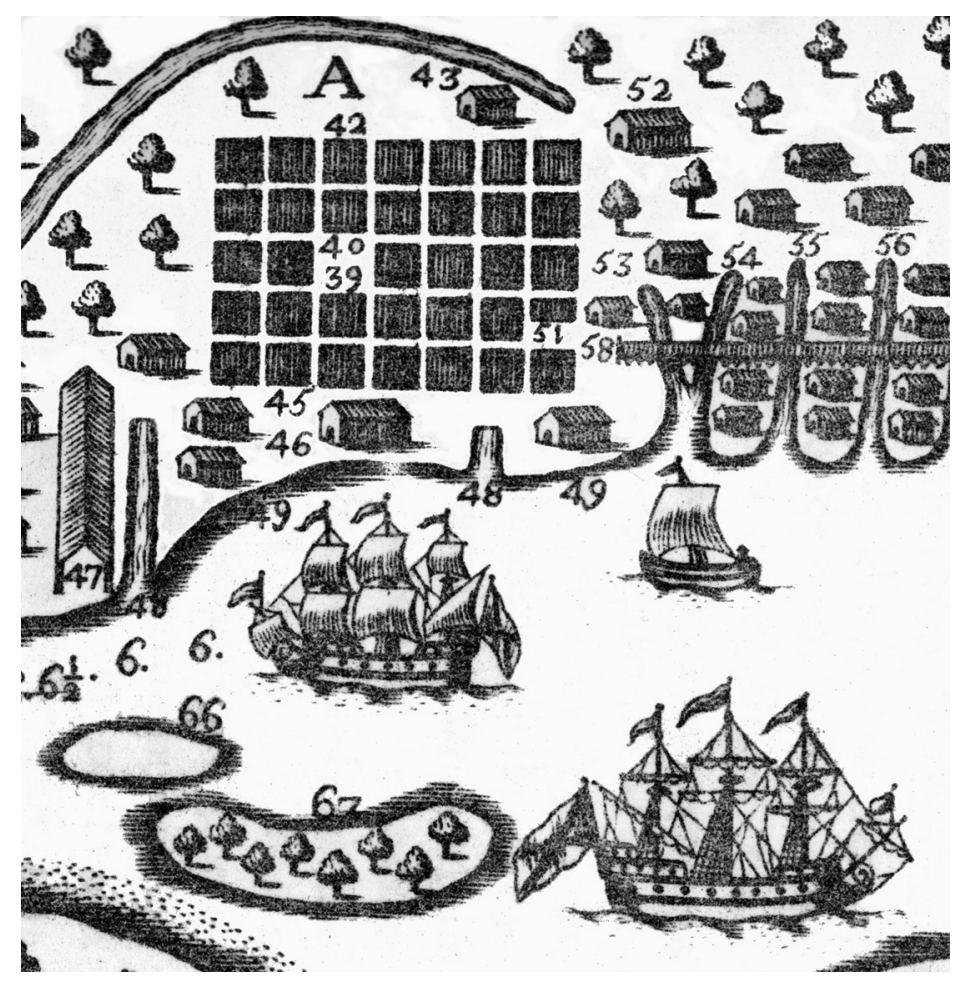

The town grew from a simple colonial village, shared by whites and Indians, into a city whose neighborhoods were densely packed and impressive to newcomers.

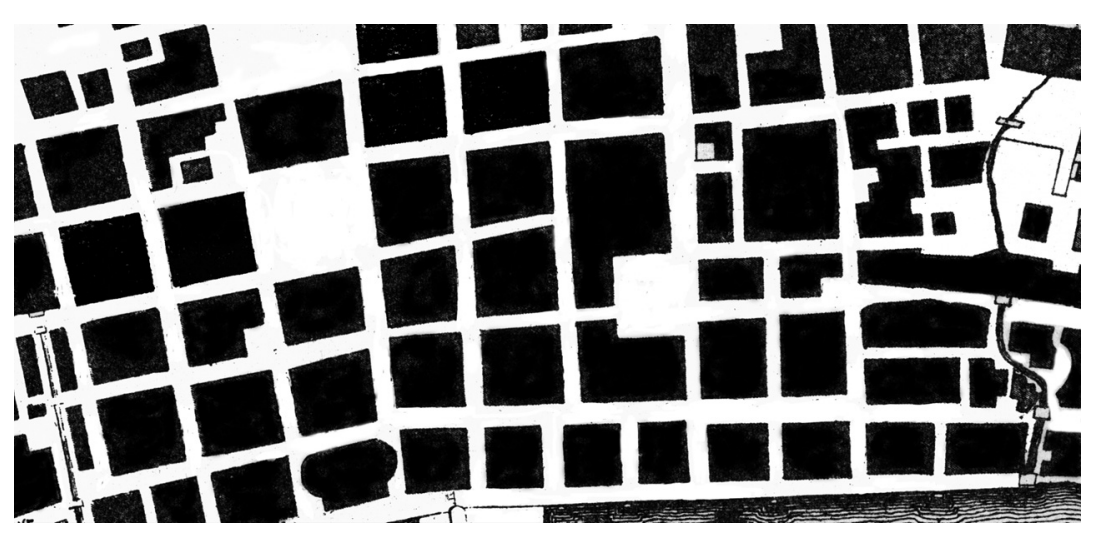




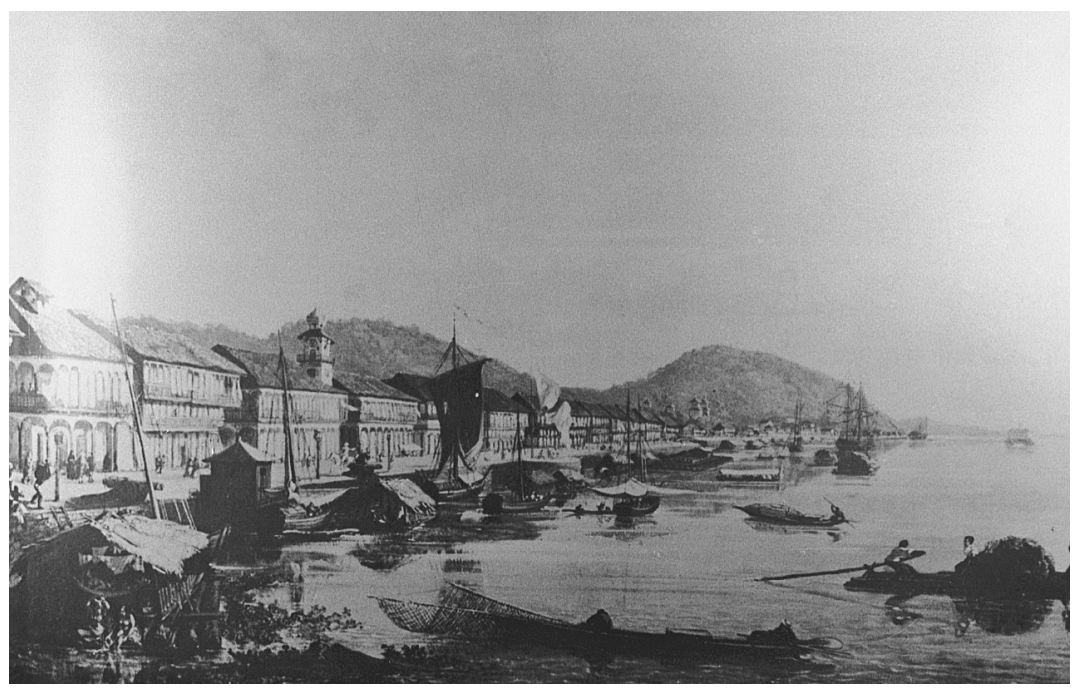

The port was always busy, especially after the war for independence.

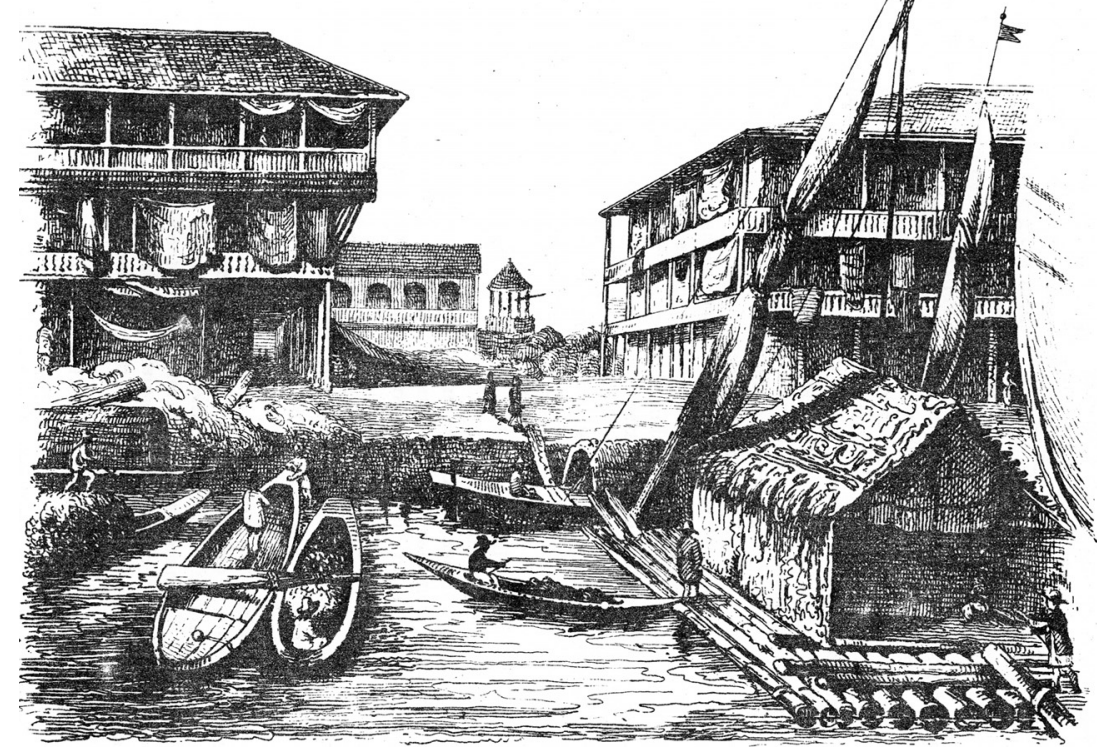




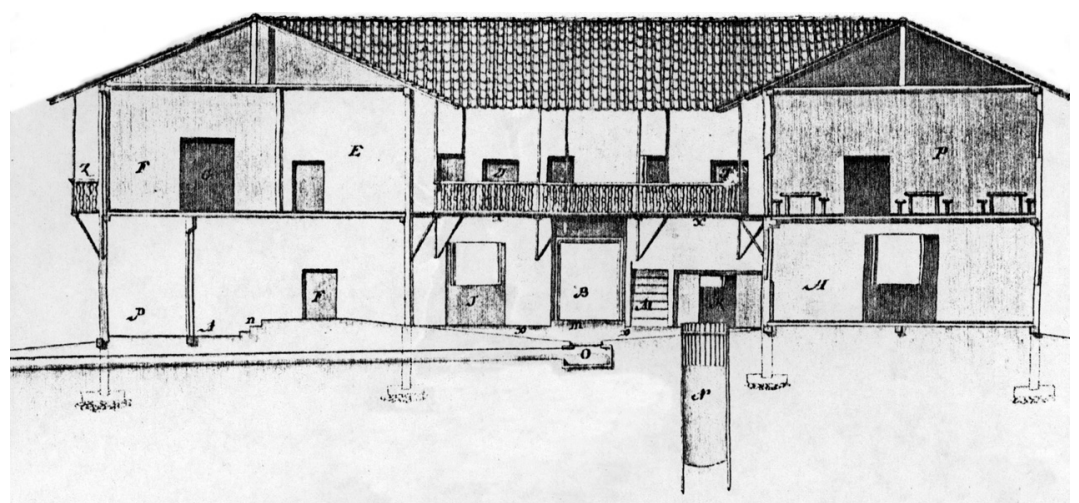

With their famous enthusiasm, the people designed factories,
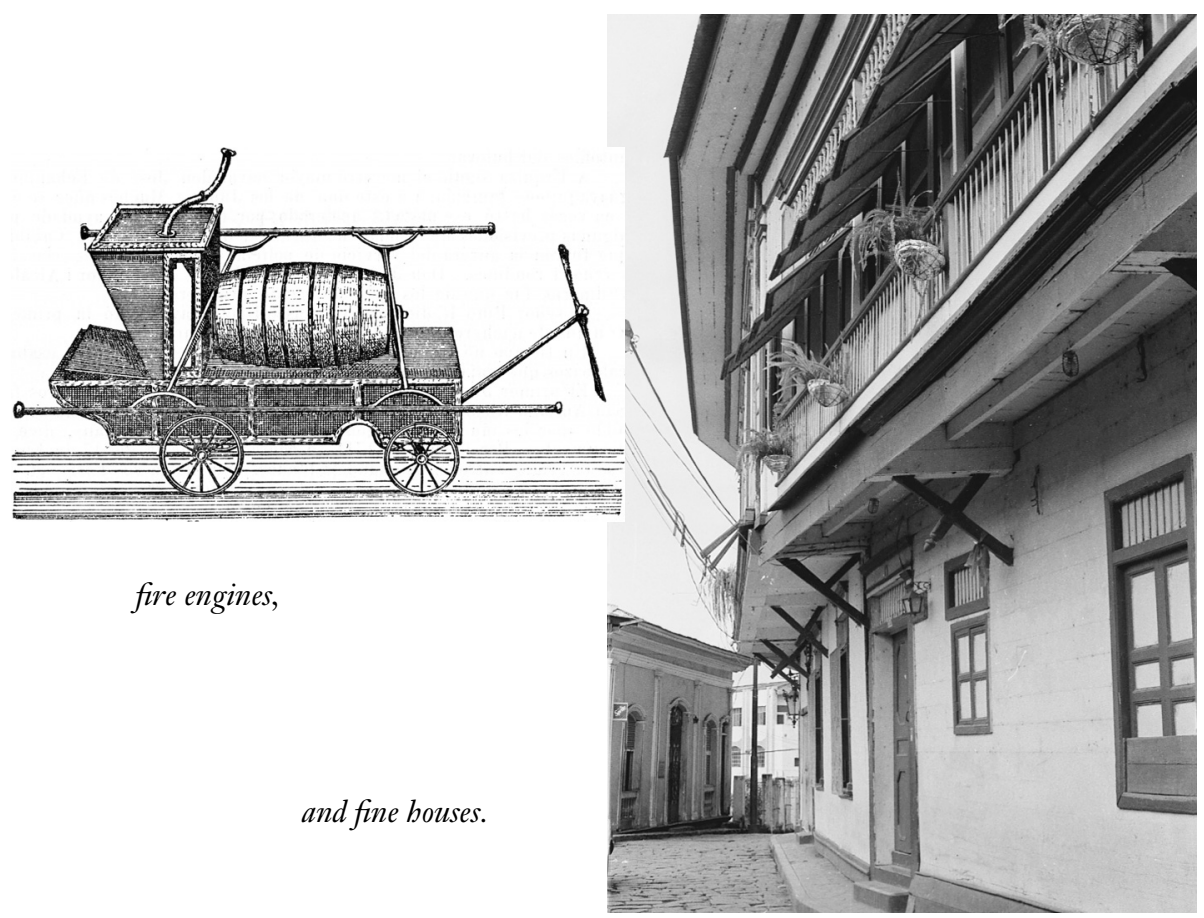

fire engines,

and fine bouses. 


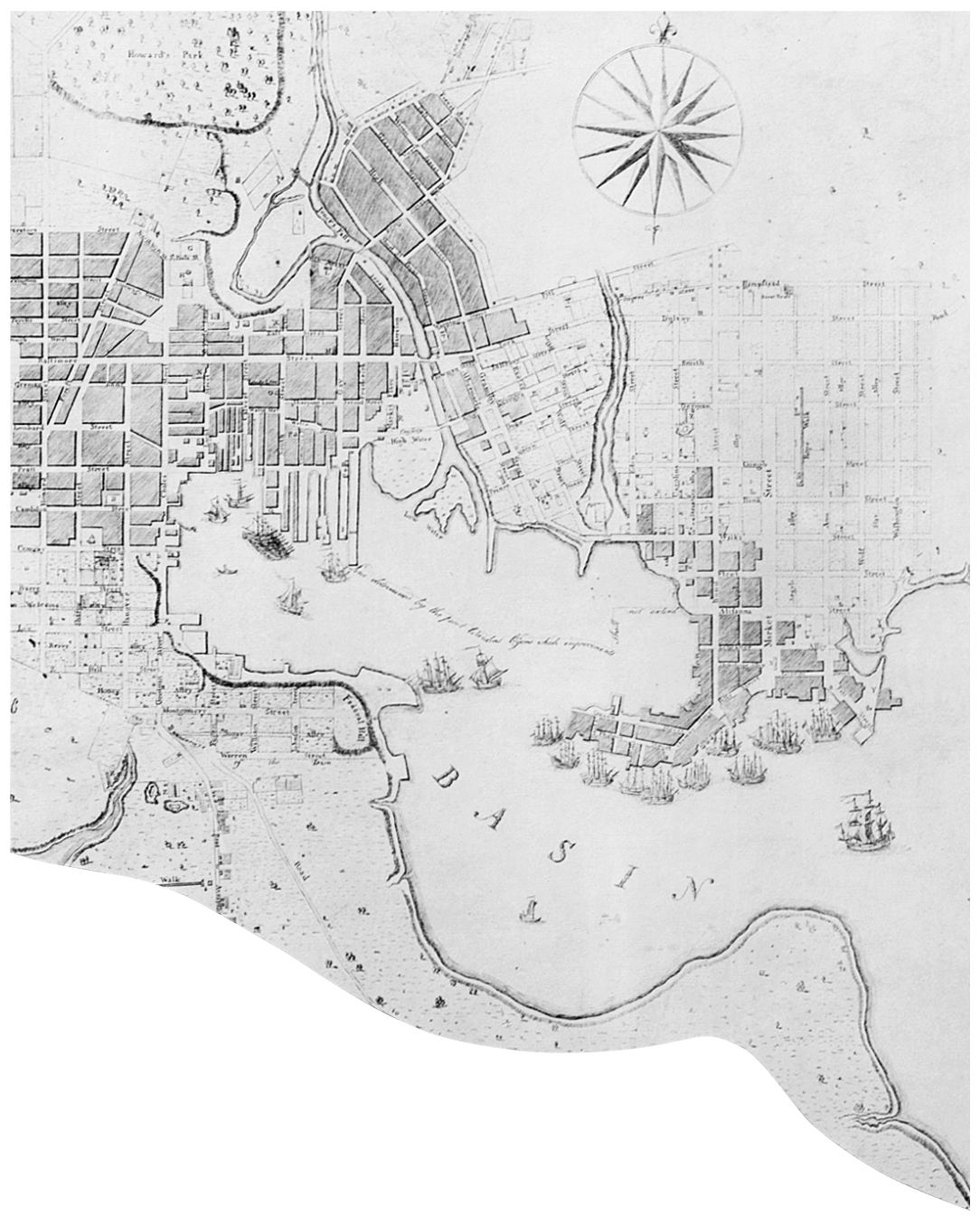

Thousands of miles away, after its own war for independence, another city grew out away from its river and into the surrounding countryside. 


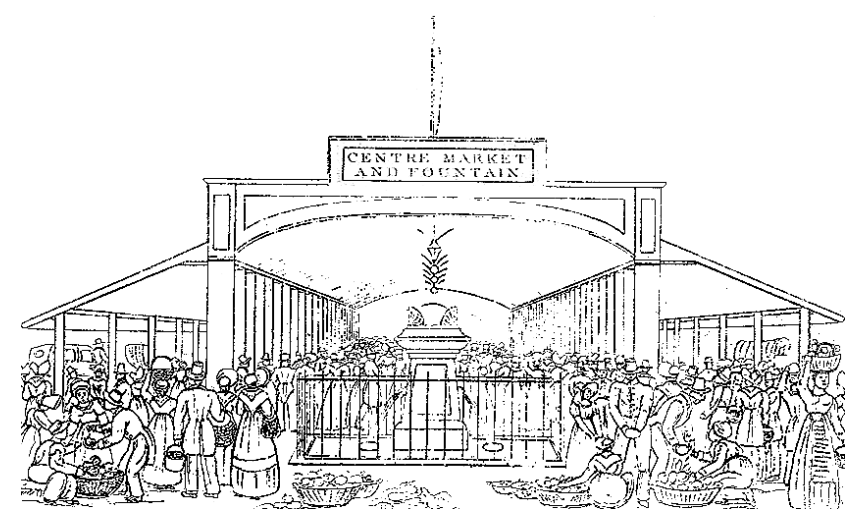

In the busy markets, crowds thronged and hawkers shouted.

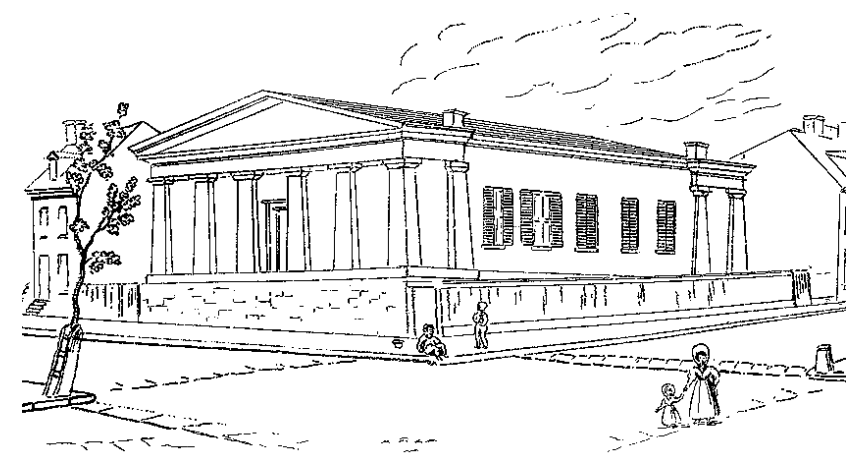

People came from all over to see the first public school

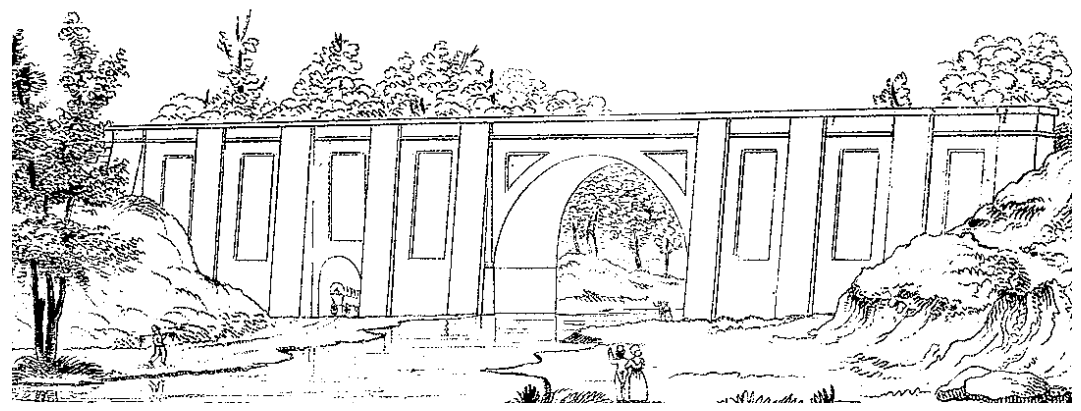

and to marvel at the aqueducts that brought water to town. 


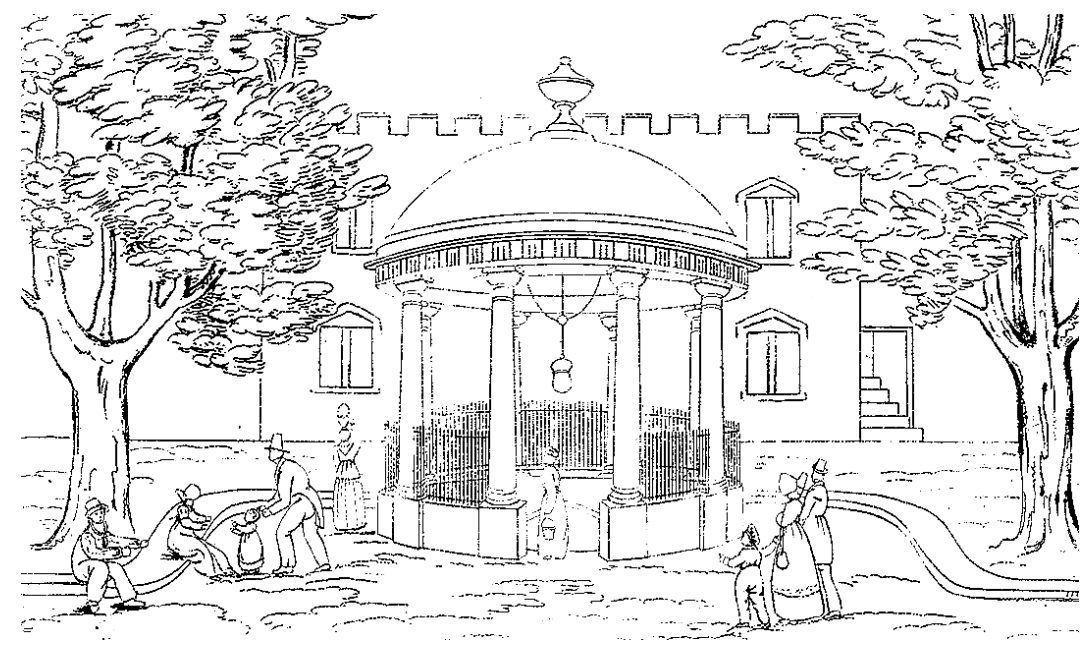

The people also loved to rest in the park and to dream of winning the lottery so that they would never have to work again.

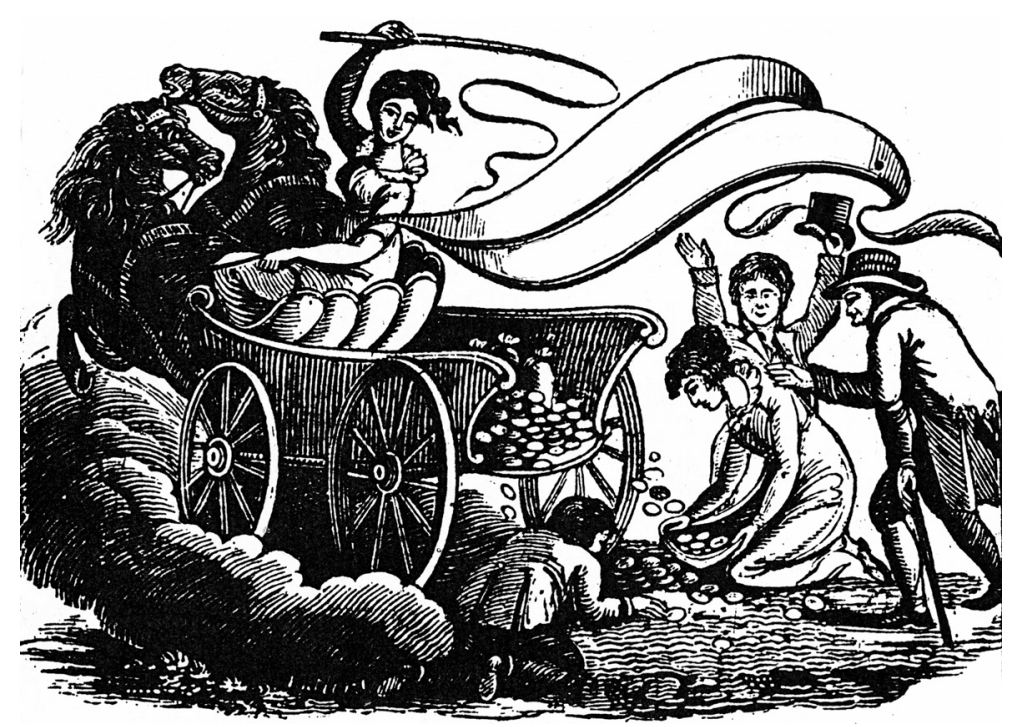




\section{Illustration Credits}

Page xvii

Top: Fragment of a map published in Dionysio de Alfredo y Herrera, Compendio Histórico de la Provincia, Partidos, Ciudad, Astilleros, Ríos y Puerto de Guayaquil, Madrid, I74I.

Воттом: Fragment of a map published in Manuel de Villavicencio, Geografía de la República del Ecuador, New York, i 858.

Page xviii

Top: "El Malecón," reproduced in Guayaquil de Ayer. Centro de Investigaciones y Cultura: Colección de Imagenes, Volumen 6. Quito: Archivo del Banco Central, I 985 .

Воттом: "Primeros Edificios en la Ciudad Nueva," from an unidentified nineteenth-century engraving reproduced in Modesto Chavez Franco, Crónicas del Guayaquil Antiquo. Guayaquil: Imprenta y Talleres Municipales, I930.

Page xix

Top: "Fábrica de Tabacos de Guayaquil," Archivo General de Indias, Sevilla, reproduced in Julio Estrada Ycaza, "La Economía de I800 a I830," Historia del Ecuador, Tomo V. Quito: Salvat Editores, I980.

MiddeE: Original model from Spain, from a I 779 engraving owned by Chavez Franco and reproduced in his Crónicas del Guayaquil Antiquo.

Воттом: Barrio las Peñas, Guayaquil. Photograph by the author.

Page $x x$

Fragment of map "Baltimore in I 792" courtesy of the Maryland Historical Society.

Page $x x i$

Top: "Centre Market" from John Latrobe, Picture of Baltimore. Baltimore:

Feilding Lucas, I832. Courtesy of Winterthur Museum and Library.

Middle: "Public School No. I" from Latrobe, Picture of Baltimore. Courtesy of Winterthur Museum and Library.

Воттом: "Carrolton Viaduct" from Latrobe, Picture of Baltimore. Courtesy of Winterthur Museum and Library.

Page xii

Top: "City Spring, Calvert Street" from Latrobe, Picture of Baltimore. Courtesy of Winterthur Museum and Library.

Воттом: From the Baltimore Biennial Advertiser, I 832. 
THIS PAGE INTENTIONALLY LEFT BLANK 